\title{
Effect of Inter-Cropping and Weed Management on the Economics of Ginger Production
}

\author{
A. Baruah ${ }^{1 *}$ and J. Deka ${ }^{2}$ \\ ${ }^{1}$ Dow AgroSciences India Pvt. Ltd., Kolkata-700157, West Bengal, India \\ ${ }^{2}$ Assam Agricultural University, Jorhat-785013, Assam, India \\ *Corresponding author
}

Keywords

Inter-cropping,

Weed management,

Hand weeding,

Metribuzin,

Oxadiargyl

Article Info

Accepted:

17 September 2019

Available Online:

10 October 2019

\section{A B S T R A C T}

A field experiment was conducted in the year 2013-14 and 2014-15 in Assam Agricultural University, Jorhat district, Assam, India to analyse the total cost and profit due to different treatment combinations of intercropping systems and chemical weed management practices in ginger. There were 16 numbers of treatment combinations, comprising of 4 intercropping systems and 4 weed management practices. Intercropping of Cowpea in between rows of Ginger and incorporated at 40 days after sowing (DAS) along with the application of Metribuzin $500 \mathrm{~g}$ ai ha ${ }^{-1}+$ hand weeding (HW) at 70, 100 and 140 days after planting (DAP) recorded higher ginger rhizome yield, gross return, net return and benefit : cost ratio.

\section{Introduction}

Ginger (Zingiber officinale Rosc.) is an important commercial crop grown for its aromatic rhizome. It is used as a spice and is also known for its medicinal benefits since several years across the globe. In the global scenario, India ranks first in terms of ginger production.

And amongst the North-eastern states, Assam has the highest production (Rahman et al., 2009). But ginger being a widely spaced crop, weeds act as a major competitor for the available resources. Controlling weeds through hand weeding is a time consuming process and expensive due to labour scarcity.

Therefore, growing of intercrops and application of pre-emergence herbicide can be a cost effective approach towards better weed management during the critical period of crop weed competition.

Thus, the current study was initiated with the intent to analyse the total cost incurred in the 
various inputs utilized in its production and also the profit that can be obtained under different treatment combinations of intercropping systems and weed management practices.

\section{Materials and Methods}

\section{Field preparation}

The experimental plots were prepared adequately and demarcated into $20 \mathrm{~m}^{2}$ subplots, comprising of 3 replications and 16 treatment combinations totalling to 48 numbers of sub-plots, accounting for a net area of $960 \mathrm{~m}^{2}$ and gross area $1482 \mathrm{~m}^{2}$.

Farm yard manure @ $10 \mathrm{t} \mathrm{ha}^{-1}$ was applied during the time of bed preparation and recommended dose of $\mathrm{N}: \mathrm{P}_{2} \mathrm{O}_{5}: \mathrm{K}_{2} \mathrm{O}$ @ 75:50:50 kg ha ${ }^{-1}$ in the form of urea $(46 \% \mathrm{~N})$, single super phosphate $\left(16 \% \mathrm{P}_{2} \mathrm{O}_{5}\right)$ and murate of potash $\left(60 \% \mathrm{~K}_{2} \mathrm{O}\right)$ were applied.

\section{Treatment details}

Treatment combination comprised of 4 Cropping Systems viz., $\mathrm{I}_{1}$ : Ginger + Cowpea (2:1); Cowpea incorporated at 40 days after sowing, $\mathrm{I}_{2}$ : Ginger + Cowpea (3:1); Cowpea incorporated at 40 days after sowing, $\mathrm{I}_{3}$ : Cowpea in between rows of Ginger and incorporated at 40 days after sowing, $\mathrm{I}_{4}$ : Cowpea in between alternate rows of Ginger and incorporated at 40 days after sowing and 4 Weed Management Practices viz., $\mathrm{W}_{1}$ : Weedy (Control), $\mathrm{W}_{2}$ : Hand weeding at 40, 70, 100 and 140 days after planting, $\mathrm{W}_{3}$ : Preemergence application of Oxadiargyl $90 \mathrm{~g}$ ai ha $^{-1}+$ hand weeding at 70, 100 and 140 days after planting and $\mathrm{W}_{4}$ : Pre-emergence application of Metribuzin $500 \mathrm{~g}$ ai ha $^{-1}+$ hand weeding at 70,100 and 140 days after planting.
Planting and sowing operations followed by herbicide application

Mancozebpre-treated 'Nadia' rhizomes of ginger were planted with a seed rate of 1800 $\mathrm{kg} \mathrm{ha}^{-1}$. Good quality fodder variety of cowpea 'UPC-278' were sown in between the rows of ginger as per the treatment requirement maintaining a spacing of $5 \mathrm{~cm}$ between cowpea plants. Cowpea was sown on the same days of ginger rhizome planting. The preemergence herbicides viz., metribuzin and oxadiargyl were applied on the $3^{\text {rd }}$ day after rhizome planting with a spray volume of 500 L ha ${ }^{-1}$.Rice straw @ $4 \mathrm{tha}^{-1}$ were mulched in two splits. First mulching was done after the application of pre-emergance herbicide and second mulching at 70 DAP. Hand weeding aided with hand blade (Khurpi) was done as per the treatment schedule. Light earthing up was done at 60 and $100 \mathrm{DAP}$ for all the ginger plots except the weedy treatments. Need based plant protection measures were adopted to manage insect and diseases as recommended by Assam Agricultural University.

\section{Total cost of cultivation}

The totalcost of cultivation was calculated in hectare basis for each treatment combinations by adding individual cost incurred on the following inputs and field operations.

$\begin{array}{ll}a= & \text { Cost of land preparation } \\ b= & \text { Cost of bed preparation } \\ c= & \text { Cost of fertilizer } \\ d= & \text { Cost of ginger and cowpea } \\ \mathrm{e}= & \text { Cost of ginger planting } \\ \mathrm{f}= & \text { Cost of cowpea sowing } \\ \mathrm{g}= & \begin{array}{l}\text { Cost of herbicide and its } \\ \text { application }\end{array} \\ \mathrm{h}= & \begin{array}{l}\text { Cost of mulch ad } \\ \text { mulching }\end{array} \\ \mathrm{i}= & \text { Cost of weeding } \\ \mathrm{j}= & \text { Cost of harvesting }\end{array}$




\section{Gross return and net return}

Gross return is the value of the economic yield calculated at prevailing price. Net return was calculated by subtracting the cost of cultivation from the gross return on per hectare basis. Benefit-cost ratio was computed by dividing the net return by total cost of cultivation during the experiment.

\section{Results and Discussion}

\section{Rhizome yield of ginger $\left(\mathrm{kg} \mathrm{ha}^{-1}\right)$}

In both the years of experimentation (2013-14 and 2014-15), highest ginger yield of 7542 and $8633 \mathrm{~kg} \mathrm{ha}^{-1}$ was recorded in the treatment Cowpea in between Ginger and incorporated at 40 DAS $\left(\mathrm{I}_{3}\right)$ which was statistically at par with the treatment Cowpea in alternate rows and incorporated at $40 \mathrm{DAS}\left(\mathrm{I}_{4}\right)$.

Amongst the weed management treatments, Metribuzine $500 \mathrm{~g} \mathrm{ha}^{-1}$ pre-em+ HW 70, 100 and 140 DAP recorded significantly highest ginger yield of 7817 and $9340 \mathrm{~kg} \mathrm{ha}^{-1}$ in 201314 and 2014-15, respectively (Table 1).

Restricting the weeds below economic threshold level due to weed smothering ability of higher density of cowpea inter cropped in between all the rows of ginger with better weed control by Metribuzin could have helped the crop to put better vegetative growth and finally a higher fresh rhizome yield. Tewari $e t$ al., (1988) reported similar findings from a study on potato.

\section{Economics}

Total expenditure incurred and total returns were worked out on hectare basis for each treatment combinations by taking into account all the cultural operations, labour wages and prices of product fixed by Assam Agricultural University and prevailing prices of other inputs as listed in Table 2.

\section{Cost of cultivation (Rs.ha $\left.{ }^{-1}\right)$}

In both the years of experimentation, the lowest cost of cultivation of Rs. 1,04,774/was obtained from the treatment combinations of intercropping systems with the weedy check, as there was no labour cost in these treatments. Whereas, the highest cost of cultivation of Rs. 1,71,774/- was incurred in the treatment combinations of intercropping systems with hand weeding at 40,70, 100 and 140 DAP, as more number of labours were required in this treatment to remove weeds at 40, 70, 100 and 140 DAP (Table 3). Aliyu and Lagoke (2000) also recorded a higher cost of cultivation in hand weeded plot over herbicide treated plot.

\section{Gross return (Rs.ha' $\left.{ }^{-1}\right)$}

The highest gross return of Rs9,30,000/- and Rs 11,63,333/- per hectare in 2013-14 and 2014-15, respectively (Table 4) was obtained with the treatments combination of Cowpea in between Ginger and incorporated at 40 DAS and Metribuzin $500 \mathrm{~g} \mathrm{ha}^{-1}$ pre-em+ HW 70, 100 and $140 \mathrm{DAP}\left(\mathrm{I}_{3} \mathrm{~W}_{4}\right)$.

Amongst treatment of inter-cropping systems of Cowpea in between Ginger and incorporated at 40 DAS and amongst weed management practices 'Metribuzin $500 \mathrm{~g} \mathrm{ha}^{-1}$ pre-em+ HW 70, 100 and 140 DAP individually recorded higher rhizome yield which together contributed towards higher gross return in this treatment combination.

\section{Net return (Rs.ha $\left.{ }^{-1}\right)$}

The highest net return of Rs7,61,425/- and Rs 9,94,759/- per hectare in 2013-14 and 201415 , respectively (Table 4) was obtained with the treatment combination of Cowpea in between Ginger and incorporated at 40 DAS and Metribuzin $500 \mathrm{~g} \mathrm{ha}^{-1}$ pre-em+ HW 70, 100 and $140 \mathrm{DAP}\left(\mathrm{I}_{3} \mathrm{~W}_{4}\right)$. 
The treatment combination of Cowpea in between Ginger and incorporated at 40 DAS and Metribuzin $500 \mathrm{~g} \mathrm{ha}^{-1}$ pre-em+ HW 70, 100 and 140 DAP recorded higher gross return, thus contributing towards higher net return.

Sanwal et al., (2006) recorded highest net in Ginger: Cowpea intercropping plots, in comparison to other treatments.

\section{Benefit cost ratio (B:C)}

The highest benefit cost $(\mathrm{B}: \mathrm{C})$ ratio 4.52 and 5.90 per hectare in 2013-14 and 2014-15, respectively was obtained with the treatments combination of Cowpea in between Ginger and incorporated at 40 DAS and Metribuzin $500 \mathrm{~g} \mathrm{ha}^{-1}$ pre-em+ HW 70, 100 and 140 DAP $\left(\mathrm{I}_{3} \mathrm{~W}_{4}\right)$. This treatment combination recorded highest gross return and net return, ultimately resulting in higher benefit: cost ratio (Table 4).

Table.1 Fresh rhizome yield $\left(\mathrm{kg} \mathrm{ha}^{-1}\right)$ of ginger

\begin{tabular}{|c|c|c|}
\hline Treatments & 2013-14 & 2014-15 \\
\hline \multicolumn{3}{|l|}{ Cropping system } \\
\hline$I_{1}: G^{*}+C^{*}(2: 1) ; C$ incorp. 40 DAS & 5846 & 6175 \\
\hline$I_{2}: G+C(3: 1) ; C$ incorp. 40 DAS & 5925 & 6454 \\
\hline$I_{3}: C$ in between $G$; incorp. 40 DAS & 7542 & 8633 \\
\hline$I_{4}: C$ in alternate rows; incorp. 40 DAS & 7338 & 8505 \\
\hline $\mathrm{CD}_{\mathrm{P}=\mathbf{0 . 0 5}}$ & 419 & 635 \\
\hline \multicolumn{3}{|l|}{ Weed management } \\
\hline $\mathrm{W}_{1}:$ Weedy & 5021 & 4825 \\
\hline $\mathrm{W}_{2}: \mathrm{HW} 40,70,100$ and 140 DAP & 6533 & 7396 \\
\hline $\mathrm{W}_{3}$ :Oxadiargyl $90 \mathrm{~g} \mathrm{ha}^{-1}$ pre-em+ HW 70, 100 and 140 DAP & 7279 & 8208 \\
\hline $\mathrm{W}_{4}$ :Metribuzine $500 \mathrm{~g} \mathrm{ha}^{-1}$ pre-em+ HW 70, 100 and 140 DAP & 7817 & 9340 \\
\hline $\mathrm{CD}_{\mathrm{P}=0.05}$ & 338 & 635 \\
\hline
\end{tabular}

Table.2 Unit cost of inputs

\begin{tabular}{|c|c|c|c|}
\hline Sl. No. & Item & Unit & Cost (Rs.₹) \\
\hline $\mathbf{1}$ & Farm Yard Manure (FYM) & ton & $1000 /-$ \\
\hline $\mathbf{2}$ & Seed Rhizome & $\mathrm{kg}$ & $30 /-$ \\
\hline $\mathbf{3}$ & Cowpea seeds & $\mathrm{kg}$ & $300 /-$ \\
\hline $\mathbf{4}$ & Tractor (ploughing) & $\mathrm{ha}$ & $2800 /-$ \\
\hline $\mathbf{5}$ & Tractor (harrowing) & $\mathrm{ha}$ & $1000 /-$ \\
\hline $\mathbf{6}$ & Urea & $\mathrm{kg}$ & $9 /-$ \\
\hline $\mathbf{7}$ & Single Super Phosphate (SSP) & $\mathrm{kg}$ & $10.5 /-$ \\
\hline $\mathbf{8}$ & Mutare of Potash (MoP) & $\mathrm{kg}$ & $12 /-$ \\
\hline $\mathbf{9}$ & Metribuzin & $\mathrm{kg}$ & $2100 /-$ \\
\hline $\mathbf{1 0}$ & Oxadiargyl & $\mathrm{kg}$ & $7285 /-$ \\
\hline $\mathbf{1 1}$ & Paddy straw & ton & $1000 /-$ \\
\hline $\mathbf{1 4}$ & Labour & man day & $134 /-$ \\
\hline
\end{tabular}


Table.3 Total cost of cultivation ( $\left.\mathrm{Rs} \mathrm{ha}^{-1}\right)$

\begin{tabular}{|c|c|c|c|c|c|c|c|c|c|c|c|}
\hline Treatments & $\begin{array}{l}\text { Cost of land } \\
\text { preparation }\end{array}$ & $\begin{array}{l}\text { Cost of bed } \\
\text { preparation }\end{array}$ & $\begin{array}{c}\text { Cost of } \\
\text { fertilizers }\end{array}$ & $\begin{array}{c}\text { Cost of } \\
\text { herbicide } \\
\text { and mulch }\end{array}$ & $\begin{array}{l}\text { Cost of } \\
\text { Ginger \& } \\
\text { Cowpea }\end{array}$ & $\begin{array}{c}\text { Cost of } \\
\text { planting } \\
\text { and } \\
\text { sowing }\end{array}$ & $\begin{array}{c}\text { Cost of } \\
\text { herbicide } \\
\text { application }\end{array}$ & $\begin{array}{l}\text { Cost of } \\
\text { mulching }\end{array}$ & $\begin{array}{c}\text { Cost of } \\
\text { weeding }\end{array}$ & $\begin{array}{c}\text { Cost of } \\
\text { harvesting }\end{array}$ & $\begin{array}{l}\text { Total Cost } \\
\text { of } \\
\text { Cultivation }\end{array}$ \\
\hline$I_{1} W_{1}$ & 5000 & 16750 & 2775 & 10,000 & 43315 & 6700 & 134 & 3350 & ------ & 16750 & 104774 \\
\hline$I_{1} W_{2}$ & 5000 & 16750 & 2775 & 10,000 & 43315 & 6700 & 134 & 3350 & 67000 & 16750 & 171774 \\
\hline$I_{1} W_{3}$ & 5000 & 16750 & 2775 & 10,728 & 57825 & 6700 & 134 & 3350 & 50250 & 16750 & 170262 \\
\hline$I_{1} W_{4}$ & 5000 & 16750 & 2775 & 11,050 & 57825 & 6700 & 134 & 3350 & 48240 & 16750 & 168574 \\
\hline $\mathbf{I}_{2} \mathbf{W}_{1}$ & 5000 & 16750 & 2775 & 10,000 & 43315 & 6700 & 134 & 3350 & ------ & 16750 & 104774 \\
\hline $\mathbf{I}_{2} \mathbf{W}_{2}$ & 5000 & 16750 & 2775 & 10,000 & 43315 & 6700 & 134 & 3350 & 67000 & 16750 & 171774 \\
\hline $\mathbf{I}_{2} \mathbf{W}_{3}$ & 5000 & 16750 & 2775 & 10,728 & 57825 & 6700 & 134 & 3350 & 50250 & 16750 & 170262 \\
\hline $\mathbf{I}_{2} \mathbf{W}_{4}$ & 5000 & 16750 & 2775 & 11,050 & 57825 & 6700 & 134 & 3350 & 48240 & 16750 & 168574 \\
\hline $\mathbf{I}_{3} \mathbf{W}_{1}$ & 5000 & 16750 & 2775 & 10,000 & 43315 & 6700 & 134 & 3350 & ------ & 16750 & 104774 \\
\hline $\mathbf{I}_{3} \mathbf{W}_{2}$ & 5000 & 16750 & 2775 & 10,000 & 43315 & 6700 & 134 & 3350 & 67000 & 16750 & 171774 \\
\hline $\mathbf{I}_{\mathbf{3}} \mathbf{W}_{\mathbf{3}}$ & 5000 & 16750 & 2775 & 10,728 & 57825 & 6700 & 134 & 3350 & 50250 & 16750 & 170262 \\
\hline $\mathbf{I}_{3} \mathbf{W}_{4}$ & 5000 & 16750 & 2775 & 11,050 & 57825 & 6700 & 134 & 3350 & 48240 & 16750 & 168574 \\
\hline $\mathbf{I}_{4} \mathbf{W}_{1}$ & 5000 & 16750 & 2775 & 10,000 & 43315 & 6700 & 134 & 3350 & ------ & 16750 & 104774 \\
\hline $\mathbf{I}_{4} \mathbf{W}_{2}$ & 5000 & 16750 & 2775 & 10,000 & 43315 & 6700 & 134 & 3350 & 67000 & 16750 & 171774 \\
\hline $\mathbf{I}_{\mathbf{4}} \mathbf{W}_{3}$ & 5000 & 16750 & 2775 & 10,728 & 57825 & 6700 & 134 & 3350 & 50250 & 16750 & 170262 \\
\hline $\mathbf{I}_{4} \mathbf{W}_{4}$ & 5000 & 16750 & 2775 & 11,050 & 57825 & 6700 & 134 & 3350 & 48240 & 16750 & 168574 \\
\hline
\end{tabular}


Table.4 Benefit : Cost Ratio under different treatment combinations

\begin{tabular}{|c|c|c|c|c|c|c|c|}
\hline \multirow[t]{2}{*}{ Treatments } & \multirow{2}{*}{$\begin{array}{c}\text { Total cost of } \\
\text { cultivation (Rs.) }\end{array}$} & \multicolumn{2}{|c|}{ Gross return (Rs.) } & \multicolumn{2}{|c|}{ Net return (Rs.) } & \multicolumn{2}{|c|}{ B: C ratio } \\
\hline & & 2013-14 & 2014-15 & 2013-14 & 2014-15 & 2013-14 & 2014-15 \\
\hline $\mathbf{I}_{1} \mathbf{W}_{1}$ & 104774.00 & 481666.67 & 441666.67 & 376892.67 & 336892.67 & 3.60 & 3.22 \\
\hline $\mathbf{I}_{1} \mathbf{W}_{2}$ & 171774.00 & 601666.67 & 650000.00 & 429892.67 & 478226.00 & 2.50 & 2.78 \\
\hline$I_{1} W_{3}$ & 170262.00 & 625000.00 & 680000.00 & 454738.00 & 509738.00 & 2.67 & 2.99 \\
\hline $\mathbf{I}_{1} \mathbf{W}_{4}$ & 168574.00 & 630000.00 & 698333.33 & 461426.00 & 529759.33 & 2.74 & 3.14 \\
\hline $\mathbf{I}_{2} \mathbf{W}_{1}$ & 104774.00 & 483333.33 & 486666.67 & 378559.33 & 381892.67 & 3.61 & 3.64 \\
\hline $\mathbf{I}_{2} \mathbf{W}_{2}$ & 171774.00 & 610000.00 & 660000.00 & 438226.00 & 488226.00 & 2.55 & 2.84 \\
\hline $\mathbf{I}_{2} \mathbf{W}_{3}$ & 170262.00 & 635000.00 & 706666.67 & 464738.00 & 536404.67 & 2.73 & 3.15 \\
\hline $\mathbf{I}_{2} \mathbf{W}_{4}$ & 168574.00 & 641666.67 & 728333.33 & 473092.67 & 559759.33 & 2.81 & 3.32 \\
\hline $\mathbf{I}_{3} \mathbf{W}_{1}$ & 104774.00 & 528333.33 & 506666.67 & 423559.33 & 401892.67 & 4.04 & 3.84 \\
\hline $\mathbf{I}_{3} \mathbf{W}_{2}$ & 171774.00 & 706666.67 & 830000.00 & 534892.67 & 658226.00 & 3.11 & 3.83 \\
\hline $\mathbf{I}_{3} \mathbf{W}_{3}$ & 170262.00 & 851666.67 & 953333.33 & 681404.67 & 783071.33 & 4.00 & 4.60 \\
\hline $\mathbf{I}_{3} \mathbf{W}_{4}$ & 168574.00 & 930000.00 & 1163333.33 & 761426.00 & 994759.33 & 4.52 & 5.90 \\
\hline $\mathbf{I}_{4} \mathbf{W}_{1}$ & 104774.00 & 515000.00 & 495000.00 & 410226.00 & 390226.00 & 3.92 & 3.72 \\
\hline $\mathbf{I}_{4} \mathbf{W}_{2}$ & 171774.00 & 695000.00 & 818333.33 & 523226.00 & 646559.33 & 3.05 & 3.76 \\
\hline $\mathbf{I}_{\mathbf{4}} \mathbf{W}_{\mathbf{3}}$ & 170262.00 & 800000.00 & 943000.00 & 629738.00 & 772738.00 & 3.70 & 4.54 \\
\hline $\mathbf{I}_{4} \mathbf{W}_{4}$ & 168574.00 & 925000.00 & 1145833.33 & 756426.00 & 977259.33 & 4.49 & 5.80 \\
\hline
\end{tabular}




\section{References}

Aliyu, L. and Lagoke, S. T. O. (2000). Profitability of chemical weed control in ginger (ZingiberofficinaleRosc.) production of Northern Nigeria. Crop Protection20: 237-240.

Rahman, H.; Karuppaiyan, R.; Kishore, K. and Denzongpa, R. (2009). Traditional practices of ginger cultivation in Northeast India. Indian Journal of Traditional Knowledge8(1): 23-28.
Sanwal, S. K.; Yadav, R. K.; Yadav, D. S.; Rai, N. and Singh, P. K. (2006). Ginger-based intercropping: highly profitable and suitable in mid hill agroclimatic conditions of North east hill region. Vegetable Science33(2): 160163.

Tewari, A. N.; Rathi, K. S.; Singh, J. P.; Pandey, R. A. and Singh, S. K. (1988). Studies on weed control in potato. Indian Journal of Agronomy 33(2): $121-124$.

\section{How to cite this article:}

Baruah, A. and Deka, J. 2019. Effect of Inter-Cropping and Weed Management on the Economics of Ginger Production. Int.J.Curr.Microbiol.App.Sci. 8(10): 2275-2281. doi: https://doi.org/10.20546/ijcmas.2019.810.264 